\title{
Revisiting George Romanes' "Physiological Selection" (1886)
}

\author{
Donald R. Forsdyke ${ }^{1}$ (D)
}

Published online: 20 July 2020

c) Konrad Lorenz Institute for Evolution and Cognition Research 2020

\begin{abstract}
Four years after the death of Charles Darwin, his research associate, George Romanes, invoked a mysterious process"physiological selection" - that could often have secured reproductive isolation independently of, and prior to, natural selection, so leading to an origin of species. This postulate of two sequential selection modes can now be regarded as leading to modern "chromosomal," as opposed to "genic," speciation theories. Romanes" abstractions-which confounded many, but not all, of his contemporaries-equate with divergences in parental DNA sequences that impede meiotic pairing in their hybrid offspring, so rendering that offspring sterile. Unlike Darwin, Romanes saw hybrid sterility as a parental, rather than offspring, phenotype that would, within a species, reproductively isolate certain parents from each other while not impeding their crossing with other parents. This group selection would have empowered natural selection to act more advantageously than in its absence. Given suitable conditions, there could then be divergence from one species into two. The present essay introduces Romanes' "Physiological Selection; an Additional Suggestion on the Origin of Species" (published in the Journal of the Linnean Society of London: Zoology (1886) 19:337-411; available as supplementary material in the online version of this essay) for the journal's "Classics in Biological Theory" collection.
\end{abstract}

Keywords William Bateson · Charles Darwin · Group selection · Hybrid sterility · Natural selection · Origin of species

\section{Darwin's Mantle}

The closest research associate of Charles Darwin (1809-1882) was the neuroscientist/philosopher/evolutionist, George John Romanes (Fig. 1). "How glad I am that you are so young!" were Darwin's words when, with outstretched hands and a bright smile, he first met Romanes in 1874. Social divisions being more apparent than today, it should be no surprise that they hit it off immediately. Both were independently wealthy and fascinated by problems in biology. For the last eight years of Darwin's life, few had more access than Romanes (Romanes 1896; Forsdyke 2001; Schwartz 2010).

Electronic supplementary material The online version of this article (https://doi.org/10.1007/s13752-020-00354-7) contains supplementary material, which is available to authorized users.

Donald R. Forsdyke

forsdyke@queensu.ca

1 Department of Biomedical and Molecular Sciences, Queen's

University, Kingston, ON, Canada
On May 5, 1886, it is likely that various British scientists received this invitation (Romanes 1886a):

My dear sir, I hope you may find it convenient to attend the next meeting of the Linnean Society, which takes place tomorrow at 8 o'clock. I am to read a paper on a new theory upon the origin of species and should like to know what you think of it. To me it appears of considerable importance, but on this account I want to expose it to the best criticism. G. J. Romanes.

The president of the Society was also due to present a paper, but he withdrew to afford Romanes more time for his address, which lasted an hour and a half. There was then a long discussion. A subsequent editorial in The Times (August 16) hailed Romanes as "the biological investigator upon whom in England the mantle of Mr. Darwin has most conspicuously descended." His paper was published both in the Journal of the Linnean Society (Romanes 1886b) and as a series of articles in Nature. The long Linnean version may be revisited as an online supplement to this introductory essay. Some may find an embellished webpage version, 


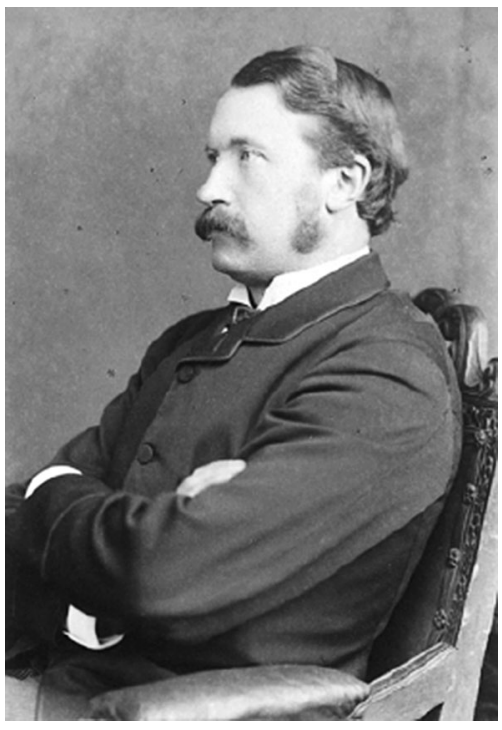

Fig. 1 George John Romanes, FRS (1848-1894). With permission of the Royal Society, London

produced at a time when internet access to 19th century journals was more difficult than today, an easier read. ${ }^{1}$

This essay begins by summarizing the paper's content and explaining aspects of Victorian terminology that predate modern phenotype-genotype distinctions and concepts of mutation and its causes. Words are usually ascribed to phenomena before we understand them (Forsdyke 2020). Thus, long before knowledge of its biochemical basis, a hand-waving Victorian could describe an organism as able to "perpetuate itself by heredity," with heredity deemed a mysterious black box that hopefully the future would open. The essay concludes with discussion of the forces aligned against and for Romanes, the latter including William Bateson, Stephen Jay Gould, and myself. Unless otherwise stated, all quotations are from Romanes (1886b).

\section{The Paper}

Romanes carefully noted, both in his title and opening remarks, that he was merely offering an "additional suggestion" to the work of his mentor, Darwin. However, the paper's main title - "Physiological Selection" - forewarned a questioning of the overarching role of natural selection itself. In the "struggle for existence" natural selection segregated

\footnotetext{
1 This essay introduces Romanes' "Physiological Selection; an Additional Suggestion on the Origin of Species" (published in the Journal of the Linnean Society of London: Zoology (1886) 19:337-411) for the journal's "Classics in Biological Theory" collection. Romanes' original article is available as supplementary material to the online version of this introduction. An embellished version is available on my webpages: https://wayback.archive-it.org/7641/20161129205617/ http:/post.queensu.ca/ forsdyke/romanes $1 . h t m$
}

the fit from the unfit, but physiological selection would segregate fit from fit. Having first revealed his conviction that (p. 337), "some cause, or causes, must have been at work in the production of species other than that of natural selection," there was then a watering down. Physiological selection was but "another factor in the formation of species, which, although quite independent of natural selection, is in no way opposed to natural selection, and may therefore be regarded as a factor supplementary to natural selection" (p. 338).

At that time differences between organisms were referred to as "variations." Romanes invoked a "particular change in the reproductive system," which we may infer for animals implied a gonadal change. This was a special type of variation-from normal fertility to seemingly abnormal sterility-that nevertheless was "subject to the laws of variation in general." Furthermore,

we are not concerned ... with its causes ... because in this respect the theory of physiological selection is in just the same position as that of natural selection; it is enough for both that the needful variations are provided, without it being incumbent on either to explain the causes which underlie the variations. (p. 354)

Breeders and horticulturalists were then familiar with blending inheritance, which is today recognized as applying to characters — such as human height - that depend on Mendelian interactions among multiple genes (Forsdyke 2016, pp. 141-156). Romanes noted that within a species "parental forms" would cross to produce either more "parental forms" or "varietal forms." The role of physiological selection was to segregate (isolate) the latter so that they would more likely cross among themselves, rather than with parental forms. By virtue of this prior reproductive isolation, the variant versions would be conserved rather than blend with parental versions.

This augured a major change in perspective. The Darwinian sequence-first natural selection and then reproductive isolation-was reversed by Romanes. Just as it was agreed that external geographical isolation could create conditions favorable to the subsequent workings of natural selection that might lead to new species, likewise in many cases an internal physiological isolation should empower subsequent speciation events based on natural selection. Thus, "when intercrossing with a parent form is in any degree prevented by physiological selection, the varietal form is free to develop diversity of character under the influence of natural selection, in the way that has been so ably shown by Mr. Darwin" (p. 387).

Intriguingly, the extent of such diversity of characters was known to differ between organisms in the wild and those raised artificially. The term "phenotype" for observed 
characters having not yet been introduced, Romanes referred to "organic types." He asked,

Why should the modifications of organic types, supposed to have been produced by natural selection, have so frequently and generally led to mutual sterility, when even greater modifications of such types known to have been produced by artificial selection continue to be mutually fertile? (p. 341)

Thus, successful crossing in the wild between members of allied species (closely resembling each other) was invariably prevented, if not by conjugational or developmental barriers, then by the sterility of their hybrid offspring. On the other hand, crossing between domestic dogs that might greatly differ anatomically, was usually productive with no sterile offspring.

Contrasting with natural selection that could affect a wide range of somatic characters, physiological selection was solely concerned with this one reproductive character-sterility—a germ-line character. Sterility was a special variation that was nevertheless subject to general laws of variation. Crossing between certain parents within a species would regularly produce a hybrid, but that hybrid would usually be sterile and so unable to continue the line. Thus, although they might produce offspring, as far as the success of their lineage was concerned the parents were reproductively isolated from each other. The degree of the sterility of their hybrid offspring correlated with their degree of reproductive isolation. With crosses between certain other parents within the species, the hybrids would be fully fertile. Thus, there was physiological selection within what was considered a single species-a selection of fit from fit.

Hybrid sterility was a collective variation in that it affected one group within a species, but not other members of the species.

The variation would be perpetuated with more certainty than could a variation of any other kind. For, in virtue of increased sterility with the parent form, the variation would not be exposed to extinction by intercrossing; while, in virtue of continued fertility within the varietal form, the variation would perpetuate itself by heredity, just as in the case of variations generally when not re-absorbed by intercrossing. (p. 352)

When not so re-absorbed, the latter variations would be subject to natural selection that would separate between fit and unfit. Hence the divergence between fit group and fit group that physiological selection had initiated could, given appropriate conditions, subsequently increase. Thus,

if from any cause a section of a species is prevented from intercrossing with the rest of its species, we might expect that new varieties - for the most part of a trivial and unuseful kind - should arise within that section, and that in time these varieties should pass into new species. (p. 349)

Romanes summarized:

Wherever any variation in the highly variable reproductive system occurs, tending to sterility with the parent form while not impairing fertility with the varietal form ..., there the physiological barrier in question must interpose, with the result of dividing the species into two parts. And it will be further evident that when such a division is effected, the same conditions are furnished to the origination of new species as are furnished to any part of a species when separated from the rest by geographical barriers. For now the two physiologically divided sections of the species are free to develop independent histories without mutual intercrossing. (p. 353)

\section{Storm of Criticism}

All this was incomprehensible to most of Romanes' contemporaries. Even though Thomas Huxley had himself declared hybrid sterility to be "the weak point" that Darwin had failed to explain (Huxley 1863; Forsdyke 2001, pp. 28-30), he and the other senior Darwinians (Alfred Wallace and Joseph Hooker) together with their junior surrogates (Francis Darwin, William Thiselton Dyer, E. Ray Lankester, and Raphael Mendola) were not convinced that Romanes had found a solution. Indeed, Huxley privately delivered the ultimate Victorian reprimand. Romanes was one of those "trying to stand on Darwin's shoulders and look bigger than he, when in point of real knowledge they are not fit to black his shoes" (Forsdyke 2001, pp. 222-224).

The Linnean Society lecture was the first salvo in an eight-year public debate between Romanes and the Darwinian establishment (Romanes 1887) that was no less colorful than its equivalent a century later between Stephen Jay Gould and the establishment of his time (Forsdyke 2004a). The issues were basically the same. Romanes (1886b) and Gould (1980) had both advocated, albeit in abstract terms, a higher level of selection involving agencies other than natural selection (Forsdyke 2001, pp. 213-214). Sadly, after a two-decade struggle with cancer, in his posthumous The Structure of Evolutionary Theory, Gould (2002, pp. 1002-1003) reversed his position.

However, Romanes had allies. An American priest/ biologist, John Gulick (1832-1923), was overtly supportive (Forsdyke 2001, pp. 207-214; Gulick 1932, pp. 383-500). Strangely less so was a young Cambridge zoologist, William Bateson (1861-1926), who at the time of the Linnean 
lecture was engaged in field work in the steppes of central Asia. He would later bring Mendel's famous 1866 paper to the world's attention. Bateson's sister, Anna, sensing that Romanes' Nature articles would be of interest, sent them to him. In a personal letter he thanked her enthusiastically (Cock and Forsdyke 2008, pp. 131-132):

Thanks for those 'Natures.' I don't agree with you that Romanes' paper is poor. It seems a fair contribution and at all events does, as he says, put the whole view on a much more logical basis. The scheme thus put will at least work logically, while the other, as left by Darwin, would not. Of course, as to the novelty of the suggestion I know nothing, and I don't much care. I did not suppose Romanes would ever write as good a paper.

Although Romanes had strongly influenced his thinking (Forsdyke 1999, 2010a), I have speculated elsewhere (Forsdyke 2010b) that Bateson's reticence to openly acknowledge agreement with Romanes was influenced by the complexities of their mutual relationships with the Cambridge Professor of Zoology and Comparative Anatomy, Alfred Newton (1829-1907).

In the final years of a sadly abbreviated life Romanes attempted to complete his great Darwin, And After Darwin trilogy. The final volume, his masterpiece, focused specifically on "post-Darwinian questions, isolation and physiological selection." Fortunately, another ally, his friend Conwy Lloyd Morgan (1852-1936), assisted its posthumous publication (Romanes 1897).

\section{Modern Interpretations}

Romanes had some sense of Mendel's work (Forsdyke 2018a) and in the early 1890s he was planning the establishment of a research station for "studying questions of hereditary transmission" (Romanes 1896, pp. 268-271). With the same purpose, in the late 1890s Rebecca Saunders and Bateson found space for plant and animal breeding in the Cambridge Botanic Gardens and in the grounds of Bateson's Granchester home (Cock and Forsdyke 2008, pp. 188-190). Through these studies Bateson was able to unite Romanes' theoretical work (albeit not acknowledged) with Mendelism, so providing foundational support for what is now known as chromosomal speciation (Forsdyke 1999, 2010a).

The spark that initiates the speciation process is sometimes of chromosomal, and sometimes of genic, origin. However, in recent decades, despite the objections of various establishment evolutionists who support the genic viewpoint (Kliman et al. 2001), the chromosomal hypothesis has won increasing support, both theoretical and experimental (Forsdyke 2004b, 2016, pp. 157-173). Our genetic material is like a language in that there is a primary message and, secondarily, a collective accent or dialect. As recognized by George Bernard Shaw a century ago, differences in accents can have reproductive consequences (Forsdyke 2001, p. $9)$. The primary message is usually genic and relates to the order of DNA bases, whereas accent relates to base composition (more of certain base "letters" than others; e.g., a high percentage of guanine and cytosine; $\mathrm{GC} \%$ ). Composition is an expression of fundamental oligonucleotide frequencies that must complement between maternal DNA and paternal DNA when their chromosomes pair during meiosis in the gonad of their child. A reproductive consequence of failure to pair is sterility (Forsdyke 2017, 2018b, 2019a, b). This is the collective variation that constitutes Romanes' "physiological barrier."2

\section{Summary}

1. Romanes postulated a type of selection-physiological selection - that differs from natural selection.

2. Physiological selection can initiate the reproductive isolation that precedes speciation.

3. This can now be related to the meiotic pairing of chromosomes.

4. Knowing how species originate is fundamental to our understanding of living forms.

Acknowledgments Queen's University hosts my evolution webpages (https://archive-it.org/collections/7641).

\section{References}

Cock AG, Forsdyke DR (2008) "Treasure your exceptions." The science and life of William Bateson. Springer, New York

Forsdyke DR (1996) Different biological species "broadcast" their DNAs at different $(\mathrm{G}+\mathrm{C}) \%$ "wavelengths". J Theor Biol 178:405-417

Forsdyke DR (1999) Two levels of information in DNA: Relationship of Romanes' "intrinsic" variability of the reproductive system, and

\footnotetext{
2 There is an intriguing personal aspect to this essay. Bioinformatic analyses of DNA sequences led to a view of the origin of species (Forsdyke 1996) that, in broad outline, was relatively simple. Indeed, so simple that I wondered whether one of the Victorians close to Darwin had anticipated me. After following several false trails, I came across Romanes in 1997 and learned that he was born in 1848, not as I had imagined in the UK, but in Canada. Surprising enough, but there was more. He was born in the Canadian city where I have worked since 1968, and in the block of houses in that city where I have lived since 1982 (Forsdyke 2001, pp. 241-242). Thus, it seems likely that Romanes spent his early years but a few yards from where I am now typing these words.
} 
Bateson's "residue", to the species-dependent component of the base composition, (C+G)\%. J Theor Biol 201:47-61

Forsdyke DR (2001) The origin of species, revisited. A Victorian who anticipated modern developments in Darwin's theory. McGillQueen's University Press, Montreal

Forsdyke DR (2004a) Grant Allen, George Romanes, Stephen Jay Gould and the evolution establishments of their times. Historic Kingston 52:95-103 https://wayback.archive-it.org/7641/20161 129204633/https://post.queensu.ca/ forsdyke/romanes3.htm. Accessed 8 Jan 2020

Forsdyke DR (2004b) Chromosomal speciation: a reply. J Theor Biol 230:189-196

Forsdyke DR (2010a) George Romanes, William Bateson, and Darwin's "Weak Point." Notes Rec R Soc 64:139-154

Forsdyke DR (2010b) Romanes versus Alfred Newton. https://wayba ck.archive-it.org/7641/20161129205735/https://post.queen su.ca/ forsdyke/romanes6.htm. Accessed 8 Jan 2020

Forsdyke DR (2016) Evolutionary bioinformatics, 3rd edn. Springer, New York

Forsdyke DR (2017) Speciation: Goldschmidt's chromosomal heresy, once supported by Gould and Dawkins, is again reinstated. Biol Theor 12:4-12

Forsdyke DR (2018a) Mendel, Gregor Johann. Encyclopedia of Life Sciences. Wiley, Chichester

Forsdyke DR (2018b) The chromosomal basis of species initiation: PRDM9 as an anti-speciation gene. Biol J Linn Soc 124:139-150

Forsdyke DR (2019a) Success of alignment-free oligonucleotide (kmer) analysis confirms relative importance of genomes not genes in speciation. Biol J Linn Soc 128:239-250

Forsdyke DR (2019b) Hybrid sterility can only be primary when acting as a reproductive barrier for sympatric speciation. Biol J Linn Soc 128:779-788
Forsdyke DR (2020) Aging, DNA information and authorship: Medawar, Schrödinger and Samuel Butler. Biol Theor 15:50-55

Gould SJ (1980) Is a new and general theory of evolution emerging? Paleobiology 6:119-130

Gould SJ (2002) The structure of evolutionary theory. Harvard University Press, Cambridge

Gulick A (1932) Evolutionist and missionary John Thomas Gulick portrayed through documents and discussion. University of Chicago Press, Chicago

Huxley TH (1863) Letter to Kingsley, 30th April. In: Huxley L (ed) Life and letters of Thomas Henry Huxley, vol 1. Appleton, New York, pp 188-189

Kliman RM, Rogers BT, Noor MAF (2001) Differences in (G+C) content between species: a commentary on Forsdyke's "chromosomal viewpoint" of speciation. J Theor Biol 209:131-140

Romanes GJ (1886a) Letter to Professor Mendola. Mendola papers. Archives of Newham Borough, London

Romanes GJ (1886b) Physiological selection; an additional suggestion on the origin of species. J Linn Soc 19:337-411

Romanes GJ (1887) Physiological selection. The criticisms. Ninet Century 21:59-80

Romanes E (1896) The life and letters of George John Romanes. Longmans, Green and Co., London

Romanes GJ (1897) Darwin, and after Darwin. Volume 3. Post-Darwinian questions, isolation and physiological selection. Longmans, Green and Co., London

Schwartz JS (2010) Darwin's disciple George John Romanes, a life in letters. American Philosophical Society, Philadelphia

Publisher's Note Springer Nature remains neutral with regard to jurisdictional claims in published maps and institutional affiliations. 